\title{
Food allergy and anaphylaxis - 2046. Cloning and characterization of the gene for acidic thaumatin- like protein, an important allergen from sapodilla plum (manilkara zapota)
}

\author{
YP Venkatesh", HG Ashok Kumar, VL Hegde, SM Shetty \\ From 2nd WAO International Scientific Conference (WISC 2012) \\ Hyderabad, India. 6-9 December 2012
}

\section{Background}

Allergic reactions to sapodilla ingestion are rare; a $21 \mathrm{kD}$ protein was recognized as an allergen in sapodilla extracts by IgE-immunoblot [1]. Further, the allergen was identified as a basic thaumatin-like protein (TLP) by its $\mathrm{N}$-terminal sequence (ATFDIQNNC-) and isoelectric point. The major purpose of this study was to identify additional allergens from this tropical fruit.

\section{Methods}

A case of oral allergy syndrome to sapodilla and custard apple was investigated following approval by Institutional Ethics Committee. Sapodilla allergy was confirmed by diagnostic tests (SPT and allergen-specific IgE). Sapodilla proteins were separated on SP-Sepharose by adsorption at $\mathrm{pH} 4$ followed by step elution at pH 5 (SP1), and with increasing $\mathrm{NaCl}-0.1 \mathrm{M}$ (SP2) and 0.2 M (SP3). Forward primers and nested reverse primers specific to the SP1 component were designed based on its $\mathrm{N}$-terminal sequence and conserved regions of homologous plant TLPs. PCR was performed using sapodilla (cv. cricket ball) leaf genomic DNA as template.

\section{Results}

SPT and allergen-specific IgE were positive. ELISA revealed that IgE from allergic serum recognized two $21 \mathrm{kD}$ proteins - one in the SP1 pool and the other in the SP2 pool; the $21 \mathrm{kD}$ protein in SP2 was identified as basic TLP. The N-terminal sequence of SP1 component was found to be ATFDVVNQCTFTVWAGASPGGGKQL- which was identified as an additional TLP. Sequence analysis of overlapping PCR products revealed an almost fulllength gene (603 bases; GenBank accession JN624813.1) corresponding to acidic TLP (residues 8-207 of sapodilla acidic TLP and lacking the N-terminal 7 residues). Phylogenetic analysis shows that sapodilla acidic TLP is evolutionarily related to the allergenic TLPs from olive and kiwi fruits, all belonging to the order Ericales.

\section{Conclusions}

A partial gene coding for sapodilla acidic TLP representing $97 \%$ of the mature sequence has been cloned. Sapodilla acidic TLP has weak $\beta$-1,3-glucanase activity and is an important allergen belonging to the TLP family of pollen and fruit allergens [2].

Published: 23 April 2013

\section{References}

1. Hegde VL, Venkatesh YP: Oral allergy syndrome to sapodilla (Achras zapota). J Allergy Clin Immunol 2002, 110:533-534.

2. Breiteneder $\mathrm{H}$ : Thaumatin-like proteins - a new family of pollen and fruit allergens. Allergy 2004, 59:479-481.

doi:10.1186/1939-4551-6-S1-P131

Cite this article as: Venkatesh et al:: Food allergy and anaphylaxis - 2046. Cloning and characterization of the gene for acidic thaumatin-like protein an important allergen from sapodilla plum (manilkara zapota). World Allergy Organization Journal 2013 6(Suppl 1):P131. 